\title{
ANTICONVULSANT ACTIVITY OF RAUWOLFIA TETRAPHYLLA LEAF EXTRACT IN SWISS ALBINO MICE
}

\begin{abstract}
AADITYA SINGH ${ }^{1 *}$, SHALINI TRIPATHI ${ }^{2}$, SINGH PN $^{3}$
${ }^{1}$ Department of Pharmaceutical Sciences, Aryakul College of Pharmacy and Research, Lucknow, Uttar Pradesh, India. ${ }^{2}$ Department of Pharmaceutical Sciences, Rameshwaram Institute of Technology and Management, Uttar Pradesh, India. ${ }^{3}$ Department of Pharmaceutics, Indian Institute of Technology, BHU, Varanasi, Uttar Pradesh, India. Email: aadityasingh85120@gmail.com
\end{abstract}

Received: 07 July 2018, Revised and Accepted: 01 November 2018

ABSTRACT

Objective: Rauvolfia tetraphylla is a plant potentially applicable in Ayurvedic and Unani System of Medicine for the treatment of various diseases. However, the anticonvulsant activity of this plant has not been reported and studied. Therefore, the ethanolic extract of leaf from the plant $R$. tetraphylla is used to evaluate anticonvulsant activity.

Methods: Anticonvulsant activity was screened using maximal electroshock seizure (MES) model and pentylenetetrazole (PTZ)-induced seizure model in Swiss albino mice. The ethanolic extract was also evaluated for rutin and gallic acid content by high-performance thin-layer chromatography studies.

Results: Rutin and gallic acid contents were found as $15.60 \%$ and $7.81 \%$, respectively. Ethanolic leaf extract (100-800 mg/kg) significantly reduced the duration of seizures which was induced by MES. The same doses also protected animals from PTZ-induced tonic seizures.

Conclusion: The study demonstrates that $R$. tetraphylla plant leaves have significant anticonvulsant activity.

Keywords: Anticonvulsant, High-performance thin-layer chromatography, Rauvolfia tetraphylla.

(C) 2019 The Authors. Published by Innovare Academic Sciences Pvt Ltd. This is an open access article under the CC BY license (http://creativecommons. org/licenses/by/4. 0/) DOI: http://dx.doi.org/10.22159/ajpcr.2019.v12i2.28334

\section{INTRODUCTION}

It is now highlighted from literature work that the interest of human is continuously increased for the use of natural drugs/phytochemicals obtained from different plant sources for the treatment of various acute and chronic diseases because of their lesser side effects along with various neurological disorders. Epilepsy is a neurological disorder of the central nervous system which is the third most common disease after stroke and Alzheimer's [1]. It is a group of related disorders where a person suffers from recurrent seizures, an abnormal, disorderly discharging of the brain's nerve cells, resulting in a temporary disturbance of motor, sensory, or mental function. It is an urgent need to search the medicinal plants that can accelerate beneficial effects in seizures.

Rauvolfia belongs to the family Apocynaceae and are well known for the presence of indole alkaloids [2]. Rauvolfia tetraphylla L. is native to Mexico, Central America, West Indies, and Northern South America. It has been cultivated widely as both an ornamental and traditional medicine. It is now utilized throughout to tropics including Australia, Indonesia, China and India. Rouwolfia popularly used in Ayurvedic and Unani System of Medicines along with a part of folk remedies of most of the Asian countries [3]. It is commonly known as "Be still tree" or "Devil-pepper" and in Hindi as Barachandrika. The alkaloids isolated from the plant material show various pharmacological activities such as antipsychotic, antimicrobial, anti-inflammatory, anticancer, antihypertensive, antidiarrheal, and antioxidant [4]. It has been cultivated both as ornamental and traditional medicine and are available as endangered medicinal plant of Odisha (India) as shrub for the treatment of epilepsy, insomnia, wound, fever, colic, and urinary retention in Ayurveda. The present manuscript describes the anticonvulsant efficacy of the ethanolic extract of $R$. tetraphylla leaf on Swiss albino mice.

\section{METHODS}

The leaves of $R$. tetraphylla were collected from the herbal garden of the National Botanical Research Institute, Lucknow, India, and authenticated by Head, Department of Pharmacognosy and Ethnopharmacology at National Botanical Research Institute, Lucknow, India. A voucher specimen no NBRI/RES/RT-20 is preserved for future reference. The leaves were dried in shade and crushed to obtain coarse powder after authentication. The solvents and chemical were analytical grade and distilled before use.

\section{Reagents, standards, and drugs}

The drug phenytoin sodium was used as standard anticonvulsant drug and obtained from Zydus Cadila Healthcare Limited, India. The pentylenetetrazole (PTZ) (R. tetraphylla) was used as standard convulsion producing agent purchased from Ranbaxy, India, and the other chemicals such as hexane, ethanol, and dimethylsulfoxide were also of analytical grade.

\section{Preparation of extract}

The leaves of $R$. tetraphylla were powdered and sieved, followed by successive extraction of powdered leaves prepared on the basis of polarity with hexane and $250 \mathrm{ml}$ of $90 \%$ ethanol using Soxhlet apparatus at $50^{\circ} \mathrm{C}$ for $80 \mathrm{~h}$. The process was repeated until complete extraction and the pooled extract were concentrated under vacuum. The resultant extract was filtered (Whatman filter paper No. 1) and was dried/concentrated under reduced pressure using rotator evaporator. The extractive value obtained was approximately $30.12 \% \mathrm{w} / \mathrm{w}$. The extract was stored in cold condition refrigerator throughout the duration of experimentation process.

\section{High-performance thin-layer chromatography (HPTLC)}

Preparation of working solutions of standard and sample

The working solution of standards ( $1 \mathrm{mg} / \mathrm{ml})$ and samples $(10 \mathrm{mg} / \mathrm{ml})$ was freshly prepared in methanol. The stock solution of standards $1 \mathrm{mg} / \mathrm{mL}$ was diluted in the same solvent to obtain a four working solutions in a concentration ranging from 0.1 to $0.4 \mathrm{mg} / \mathrm{ml}$, for calibration. 


\section{HPTLC procedure}

It is well known that HPTLC is used for quantitative analysis, for sampling about 10 microliter of sample was applied using Hamilton syringe (Camag $100 \mathrm{ml}$ syringe, Switzerland) on a pre-coated plates of silica gel, having thickness of $6 \mathrm{~mm}$. The sample was spotted $10 \mathrm{~mm}$ from the bottom and $15 \mathrm{~mm}$ from side of the plate by using Camaglinomat-V automated applicator. The applicator is facilitated by nitrogen flow providing a delivery speed of $150 \mathrm{ml} / \mathrm{s}$.

\section{Development of plates}

The layers were developed in a Camag Twin Trough Glass Chamber, which was presaturated with mobile phase toluene: ethyl acetate: formic acid (7:2.5:0.5 v/v). The plate after development was dried and spraying agent anisaldehyde sulfuric acid was applied for derivatization followed by scanning at $254 \mathrm{~nm}$ and $366 \mathrm{~nm}$. The percentage of rutin and gallic acid was calculated using the following formula [5]:

\section{$\frac{(\text { Sample area } \times \text { standard dilution } \times \text { purity }) \times 100}{(\text { Standard area } \times \text { sample dilution } \times 100)}$}

\section{Experimental animals}

TheSwiss albino mice of eithersex ofb ody weight (20-30g) were obtained from Central Animal House, Rameshwaram Institute of Pharmacy (Reg. No - 1397/ac/10 Committee for the purpose of Control and Supervision of Experimental Animal [CPCSEA]). Swiss albino mice were randomly distributed in various groups for the treatment of standard and sample drugs. They were kept at one ambient temperature of $25 \pm 1^{\circ} \mathrm{C}$ and $45-$ $55 \% \mathrm{RH}$ in polypropylene cage and acclimatized to laboratory condition before a week to start the experiment. The experimental protocols were approved by the Institutional Animal Ethics Committee constitute under Committee for the Purpose of CPCSEA, Government of India.

\section{Acute oral toxicity studies}

The acute toxicity study of an ethanolic extract of $R$. tetraphylla was done as per the OECD guideline No.420 (OECD, 2002). Swiss albino mice in three different groups of either sex were weighed and placed under standard condition. Method of CPCSEA was adopted for toxicity studies. The extracts were administered in a dose of 50 , 300,1000 , and $2000 \mathrm{mg} / \mathrm{kg}$ p.o. to different groups of mice each containing 10 animals, and mortality was observed after $25 \mathrm{~h}$. The mortality dose of animals is $2000 \mathrm{mg} / \mathrm{Kg}$.

\section{Drug treatment}

Swiss albino mice were treated both with standardized ethanolic leaf extract of $R$. tetraphylla in a dose of 200,400 , or $600 \mathrm{mg} / \mathrm{kg}$ and the standard drug phenytoin sodium in a dose of $25 \mathrm{mg} / \mathrm{kg}$ for 7 consecutive days. Saline solution is used as control using electrical (maximal electroshock seizure [MES]) and chemical (PTZ) method.

\section{Screening of anticonvulsant activity}

The Swiss albino mice were divided into five groups, and screening of anticonvulsant activity was done by MES model and PTZ model.

\section{Effect of extract on MES-induced seizures}

This is the best model for generalized seizures of tonic-clonic type [6,7]. In this model, rats receive an electrical shock of $50 \mathrm{~mA}$ and $50 \mathrm{~Hz}$ for a duration of $2 \mathrm{~s}$ to induce seizures by electroconvulsiometer. Swiss albino mice were divided into a five groups $(\mathrm{n}=6)$ : Group I, Group II, Group III, Group IV, and Group V.

Group I was served as control and received only saline water; Groups II, III, and VI get the ethanolic extract of $R$. tetraphylla in oral doses of 200 , 400 , or $600 \mathrm{mg} / \mathrm{kg}$ and the Group V gets the standard drug phenytoin sodium in a dose of $25 \mathrm{mg} / \mathrm{kg}$. The test extract was prepared in $2 \% \mathrm{v} / \mathrm{v}$ Tween 80 solution and get administered orally 1 hour before inducing convulsions and standard drug (phenytoin sodium $25 \mathrm{mg} / \mathrm{Kg}$ ) was administered 30 min before through i.p route.
Convulsions were developed by MES; different phases of the convulsions (flexor, extensor, convulsion, stupor, and recovery or death) were observed. Hind-limb tonic extension (HLTE) phase was measured as the protection of the convulsion developed by MES model.

\section{Effect of extract on PTZ-induced seizures}

The standard drug PTZ which is used for the generation of seizures was administered in a dose of $60 \mathrm{mg} / \mathrm{kg}$ i.p $60 \mathrm{~min}$ before the test drug, i.e., the ethanolic extract of $R$. tetraphylla and the parameters such as myoclonic, clonic, and tonic-clonic seizures [8] and \% protection was observed. In this model also, Swiss albino mice were divided into five groups ( $\mathrm{n}=6)$ : Group I, Group II, Group III, Group IV, and Group V; Group I is served as control, Groups II, III, and IV get the ethanolic extract in a dose of 200,400 , or $600 \mathrm{mg} / \mathrm{kg}$, and the Group V served as standard received phenytoin sodium $25 \mathrm{mg} / \mathrm{kg}$

\section{Statistical analysis}

The data obtained by different experimental parameters were statistically evaluated by SPSS software and ANOVA test followed by student's $t$-test $(\mathrm{p}<0.05)$ which was used to find the significance. All observations were expressed as mean \pm standard deviation, and the graph of each data is plotted by GraphPad Prism software.

\section{RESULTS}

\section{HPTLC}

Quantification of rutin and gallic acid was done by HPTLC; mobile phase used was toluene: ethyl acetate: formic acid (7:2.5:0.5 v/v) which shows very good resolution of spot of the sample against the standards on the HPTLC plate. HPTLC plates are visualized in ultraviolet light of $254 \mathrm{~nm}$ and $366 \mathrm{~nm}$ wavelength. Identification of the presence of rutin and gallic acid in the extract was performed by comparison of chromatogram of standard and sample, which is shown to be similar in Fig. 1. By these studies of HPTLC, the amount of rutin and gallic acid is $15.60 \%$ and $7.81 \%$, respectively (Figs. 2 and 3 )

\section{MES test}

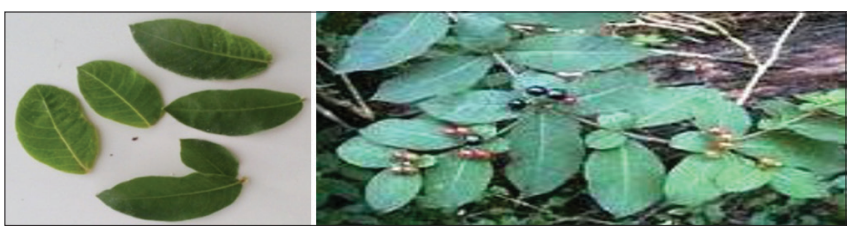

Fig. 1 Picture of leaves of Rauvolfia tetraphylla

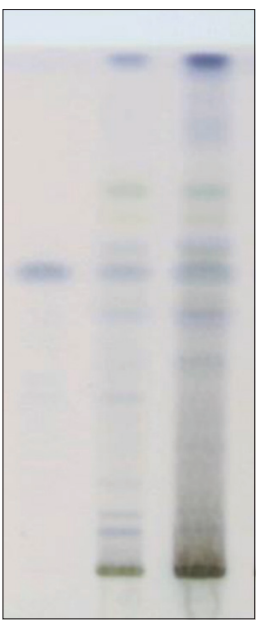

Fig. 2: High-performance thin-layer chromatography plate with spots of rutin (spot 1), gallic acid (spot 2), and ethanolic extract (spot 3) 


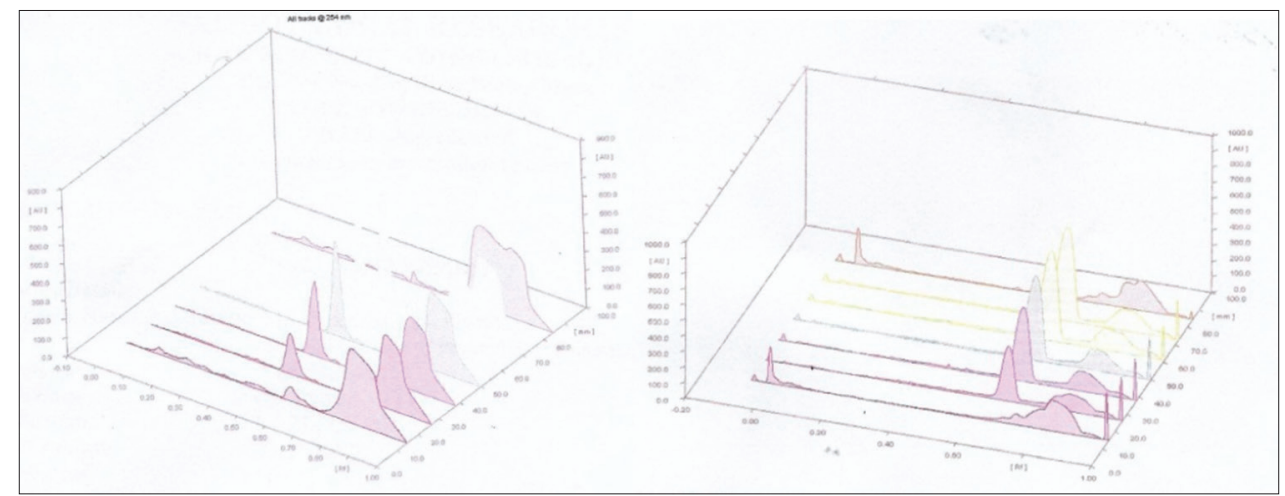

Fig. 3: Three-dimensional diagram of high-performance thin-layer chromatography densitograms for rutin and gallic acid, respectively

Table 1: Effect of alcoholic extract against MES-induced convulsion group time (s) in various phases of convulsions

\begin{tabular}{llllll}
\hline \multirow{2}{*}{ Group } & \multicolumn{5}{l}{ Time $(\mathbf{s})$ in various phases of convulsions (mean \pm SEM) } \\
\cline { 2 - 6 } & Flexion & Extension (HLTE) & Clonus & Stupor & Recovery \\
\hline Control & $3.81 \pm 0.014$ & $11.42 \pm 0.020$ & $14.07 \pm 0.577$ & $92.28 \pm 0.106$ & $120.8 \pm 1.40$ \\
Standard & $1.323 \pm 0.218^{* *}$ & $0.00 \mathrm{~s}^{* *}$ & $7.77 \pm 0.169^{* *}$ & $50.69 \pm 0.134^{* *}$ & $30.32 \pm 0.811$ \\
RT-200 & $3.77 \pm 0.026$ & $11.48 \pm 0.086$ & $13.83 \pm 0.205$ & $90.87 \pm 0.855$ & $118.23 \pm 0.700$ \\
RT-400 & $2.67 \pm 0.020^{* *}$ & $4.38 \pm 0.023^{* *}$ & $13.49 \pm 0.410$ & $89.84 \pm 0.622^{*}$ & $98.53 \pm 0.232$ \\
RT-600 & $62 \pm 0.030^{* *}$ & $2.65 \pm 0.308^{* *}$ & $9.29 \pm 0.014^{* *}$ & $58.05 \pm 0.226^{* *}$ & $96.78 \pm 0.410$ \\
\hline
\end{tabular}

HLTE: Hind-limb tonic extension, SEM: Standard error of the mean, MES: Maximal electroshock seizure

Table 2: Effect of alcoholic and aqueous extract on PTZ-induced convulsions

\begin{tabular}{|c|c|c|c|c|}
\hline \multirow[t]{2}{*}{ Drug } & \multicolumn{4}{|c|}{ Onset time in seconds (mean \pm SEM) } \\
\hline & Dose (mg/Kg b.w.) & Jerks & Clonus & Extensor \\
\hline Vehicle & & $48.72 \pm 0.085$ & $77.12 \pm 0.540$ & $278.11 \pm 0.220$ \\
\hline Standard (phenytoin $\mathrm{Na}$ ) & 25 & $0.00 \pm 0.000^{* *}$ & $0.00 \pm 0.000^{* *}$ & $0.00 \pm 0.000^{* *}$ \\
\hline Rauvolfia tetraphylla & 200 & $47.89 \pm 0.227$ & $77.97 \pm 0.490$ & $280.28 \pm 1.045$ \\
\hline Rauvolfia tetraphylla & 400 & $49.62 \pm 0.248$ & $79.05 \pm 0.115^{*}$ & $298.51 \pm 0.815^{* *}$ \\
\hline Rauvolfia tetraphylla & 600 & $49.78 \pm 0332 *$ & $80.57 \pm 0.425^{* *}$ & $317.22 \pm 0.030^{* *}$ \\
\hline
\end{tabular}

Values are mean \pm SEM, $\mathrm{n}=6 .{ }^{*} \mathrm{p}<0.01,{ }^{*} \mathrm{p}<0.05$ significant when compared to control. SEM: Standard error of the mean, PTZ: Pentylenetetrazole

MES-induced tonic seizures can be prevented either by drugs that inhibit voltage-dependent $\mathrm{Na}+$ channels such as phenytoin, valproate, felbamate, and lamotrigine or by drugs that block glutaminergic excitation mediated by n-methyl-D-aspartate receptor, such as felbamate. $R$. tetraphylla alcoholic extract may follow any one of the above mechanisms. The result of anticonvulsant effect of $R$. tetraphylla leaves against MES- and PTZ-induced convulsions is shown in Tables 1 and 2, respectively. The one-way ANOVA analysis of the data observed indicated that alcoholic extract exhibited significant antiseizure effect against MES- and PTZ-induced seizures. Control group animals exhibited HLTE of $11.42 \pm 0.020 \mathrm{~s}$ after the delivery of an electroshock. Ethanolic extract at a dose of $200 \mathrm{mg} / \mathrm{kg}$ body weight shown very less effect on total duration of HLTE, while at the dose of 400 and $600 \mathrm{mg} / \mathrm{kg}$, it reduced the duration of HLTE to $4.38 \pm 0.023$ and $2.65 \pm 0.308 \mathrm{~s}$, respectively. Statistically significant results were observed with alcoholic extract at the dose of 400 and $600 \mathrm{mg} / \mathrm{kg}$ with $\mathrm{p}<0.01$.

\section{PTZ-induced seizures}

In PTZ-induced seizures, alcoholic extracts at a dose of 400 and $600 \mathrm{mg} / \mathrm{kg}$ b.w. exhibited delayed onset of clonus $79.05 \pm 0.115$ and $80.57 \pm 0.425 \mathrm{~s}$, respectively, in comparison to control $77.12 \pm 0.540 \mathrm{~s}$. For the extensor phase, alcoholic extract at a dose of 400 and $600 \mathrm{mg} / \mathrm{kg}$ exhibited $298.51 \pm 0.815$ and $317.22 \pm 0.030 \mathrm{~s}$, respectively, as significant anticonvulsant activity in comparison to control extensor $(278.11 \pm 0.220 \mathrm{~s}$ ).
Furthermore, the study is, however, necessary to elucidate the exact mechanism of action and the active principle responsible for above activity.

\section{DISCUSSION}

The study was designed to elucidate the antioxidant constituents present in the plant through HPTLC as well as to screen the anticonvulsant activity in ethanolic leaf extract of $R$. tetraphylla. HPTLC results show that the presence of rutin and gallic acid in the extract was $15.60 \%$ and $7.81 \%$, respectively. The antioxidant constituents were determined through HPTLC because it also helps to improve the anticonvulsant symptoms in the patients. Anticonvulsant screening was done using two models, that is, MES- and PTZ-induced model. In MES model, the extension (HLTE) phase in three groups RT-200, RT-400, and RT-600 was found to be $11.48 \pm 0.086,4.38 \pm 0.023$, and $2.65 \pm 0.0308 \mathrm{~s}$, respectively, which shows that there was a reduction in its duration. There was complete abolition of the extensor phase in the standard group of phenytoin. From the above findings, it can be observed that the ethanolic leaf extract of $R$. tetraphylla reduced the extensor phase of convulsion in the dose-dependent manner $[9,10]$ with maximum effect seen at the dose of $600 \mathrm{mg} / \mathrm{kg}$. In PTZ model, the onset of extensor phase increases with an increase in dose from 200 to $600 \mathrm{mg} / \mathrm{Kg}$ body weight.

\section{CONCLUSION}

It was found that ethanolic extract of $R$. tetraphylla leaves (dose 400 and $600 \mathrm{mg} / \mathrm{kg}$ body weight) had significant activity against MES and PTZ convulsions when compared to control groups. The plant would be 
of great value to confirm these findings for different other doses and to find the exact mechanism of action with further studies on experimental animals and finally doing clinical studies to make it available for use in human beings in a commercial way.

\section{AUTHORS' CONTRIBUTIONS}

Aaditya Singh: Designed and performed the activity and compiled it in the manuscript. Shalini Tripathi and P.N Singh: Supervisors of research work and reviewed and edited the manuscript.

\section{CONFLICTS OF INTEREST}

Authors declare no conflicts of interest.

\section{REFERENCES}

1. Löscher W, Schmidt D. Which animal models should be used in the search for new antiepileptic drugs? A proposal based on experimental and clinical considerations. Epilepsy Res 1988;2:145-81.

2. Amabeoku GJ, Chikuni O. Cimetidine-induced seizures in mice. Biochem Pharmacol 1993;46:2171-5.

3. White HS. Preclinical development of antiepileptic drugs: Past present and future direction. Epilepsia 2003:44:2-8.

4. Koche D, Shirsat R, Imran S, Bhadange DG. Phytochemical screening of eight traditionally used ethno medicinal plants from Akola district (MS) India. Int J Pharm Bio Sci 2010;1:253-56.

5. Vezzani A, French J, Bartfai T, Baram TZ. The role of inflammation in epilepsy. Nat Rev Neurol 2011;7:31-40.

6. Iqbal AA, Khan FA, Khan M. Ethno-phyto-pharmacological overview on Rauwolfia tetraphylla L. Int J Pharm Phytopharm Res 2013;2:247-51.

7. Doshi GM, Zine SP, Chaskar PK, Une HD. Solicitation of HPLC and HPTLC techniques for determination of Rutin from Polyalthia longifolia Thwaites. Pharmacogn Res 2014;6:234-9.

8. Nirmala D. Studies on anticonvulsant activity of annacyclus pyrethrum in albino mice. Asian J Pharm Clin Res 2015;8:178-87.

9. Thakuria N, Das S, Dewan B. Anticonvulsant activity of citrus maximus leaves in experimental animal models. Asian J Pharm Clin Res 2016;9:1-3.

10. Jakaria MD, Tareq SM, Ibrahim M, Bokhtearuddin S, Rauvolfiatetraphylla L. (Apocynaceae): A pharmacognostical, phytochemical and pharmacological review. J Chem Pharm Res 2016;8:114-20.

11. Gurupriya S, Cathrine L, Pratheema P. HPTLC method for the determination of lupeol from Andrographis echioides leaves. Int $\mathrm{J}$ Pharm Pharm Sci 2018;10:102-7. 